Instructions for authors, subscriptions and further details:

\title{
Who is a Real Man? The Gender of Trumpism
}

C.J. Pascoe ${ }^{1}$

1) University of Oregon, USA

Date of publication: June $21^{\text {st }}, 2017$

Edition period: June 2017 - October 2017

To cite this article: Pascoe, C.J. (2017). Who is a Real Man? The Gender of Trumpism. Masculinities and Social Change,6(2),119-141. doi:

10.17583/MCS.2017.2745

To link this article: http://doi.org/10.17583/MCS.2017.2745

\section{PLEASE SCROLL DOWN FOR ARTICLE}

The terms and conditions of use are related to the Open Journal System and to Creative Commons Attribution License (CC-BY). 
MCS - Masculinities and Social Change Vol. 6 No. 2 June 2017

pp. 119-141

\section{Who is a Real Man? The Gender of Trumpism}

C. J. Pascoe

University of Oregon

\section{Abstract}

The rise of Trumpism exemplifies a contest over masculinity, over who qualifies as a "real man." This contest being waged not only by some obvious actors President Trump, his supporters and representatives; it is a contest also waged by those who oppose the current administration and are perhaps actively working against the perpetuation of gender inequality. The themes deployed by Trumpists and anti-Trumpists alike address a core component of masculinity in the global west - dominance. Through sexualized processes of confirmation and repudiation multiple actors in this political and social moment draw on and deploy understandings of normative masculinity as dominance - dominance over women and dominance over other, less masculine, men. Both the Trumpist and antiTrumpist movements exemplify similar discourses of masculinized dominance in which social actors claim masculinity through discourses and symbols of "compulsive heterosexuality" and divest others of it through the emasculating practices of a "fag discourse." The story of Trumpism and movements against it is an example of the tenacity of inequality in gendered discourses.

Keywords: masculinity, sexism, homophobia, Trump, politics 
MCS - Masculinities and Social Change Vol. 6 No. 2 June 2017 pp. 119-141

\title{
¿Quién es un Hombre Real? El Género del Trumpism
}

\author{
C. J. Pascoe \\ University of Oregon
}

\section{Resumen}

El auge del Trumpism ejemplifica un concurso sobre la masculinidad, sobre quién es realmente un "hombre verdadero." Este concurso está liderado por algunos actores obvios - el presidente Trump, sus partidarios y representantes. Es una contienda también emprendida por quienes se oponen a la actual administración y tal vez están trabajando activamente contra la perpetuación de la desigualdad de género. Los temas desplegados por los Trumpists y anti-Trumpists plantean el tratamiento de un componente fundamental de la masculinidad en Occidente: la dominación. A través de procesos sexualizados de confirmación y rechazo, en la actualidad una multitud de actores políticos y sociales aprovechan y despliegan prácticas propias de la masculinidad normativa como la dominación: dominio sobre las mujeres y dominio sobre otros hombres menos masculinos. Tanto los movimientos Trumpistas como los anti-Trumpistas ejemplifican discursos similares de dominación masculinizada en los que los actores sociales reclaman la masculinidad a través de discursos y símbolos de la heterosexualidad compulsiva y despojan a otros de ella a través de las prácticas emasculadoras de un "discurso fag". Flexible y adaptable. Lo que al principio parece una mejora (una protesta a gran escala contra el sexismo de un político, por ejemplo), puede ser un ejemplo de corrientes sociales complejas.

Palabras clave: masculinidad, sexismo, homofobia, Trump, políticos 


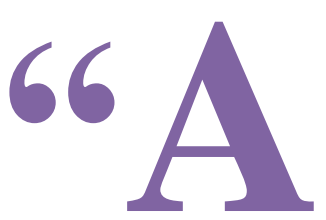

re you a Trump Man or a decent man? Time to choose," asked and instructed a headline in the Guardian several months after the inauguration of the United States' President Donald Trump (Penny, 2017). Different modes of manhood, masculinity, and misogyny have been at the heart of his rise to power (Bordo, 2017; Bridges \& Pascoe, 2016). According to many, especially those on the American and global left, the President enacts and represents an outmoded understanding of masculinity - a boorish, sexist, unsophisticated, homophobic, xenophobic, racist, nationalist manhood. As such his election victory threatened to return the United States to a time before less powerful groups had begun to realize some of the hard fought protections implemented in the preceding decade(s).

Take for instance the recording of a 2005 conversation the now president had with American television personality, Billy Bush about women:

Trump: I moved on her, actually. You know, she was down on Palm Beach. I moved on her, and I failed. I'll admit it.

Unknown: Whoa.

Trump: I did try and fuck her. She was married.

Unknown: That's huge news.

Trump: No, no, Nancy. No, this was [unintelligible] — and I moved on her very heavily. In fact, I took her out furniture shopping. She wanted to get some furniture. I said, "I'll show you where they have some nice furniture." I took her out furniture - I moved on her like a bitch. But I couldn't get there. And she was married. Then all of a sudden I see her, she's now got the big phony tits and everything. She's totally changed her look.

Billy Bush: Sheesh, your girl's hot as shit. In the purple.

Trump: Whoa! Whoa!

Bush: Yes! The Donald has scored. Whoa, my man!

Trump: Look at you, you are a pussy.

Trump: All right, you and I will walk out.

Trump: Maybe it's a different one.

Bush: It better not be the publicist. No, it's, it's her, it's -

Trump: Yeah, that's her. With the gold. I better use some Tic Tacs just in case I start kissing her. You know, I'm automatically 
attracted to beautiful - I just start kissing them. It's like a magnet. Just kiss. I don't even wait. And when you're a star, they let you do it. You can do anything.

Bush: Whatever you want.

Trump: Grab 'em by the pussy. You can do anything. (The New York Times, 2016).

These comments resurfaced during the presidential campaign. Their circulation throughout multiple media outlets generated outrage and eventually provided the symbol at the heart of the largest one-day international protest in history, the "pussy hat."

The conversation received so much attention, in fact, that the moderator of the $2^{\text {nd }}$ presidential debate ${ }^{1}$, Anderson Cooper, asked candidate Trump about them. Trump responded with a metaphorical shrug, saying "Yes, I am very embarrassed by it and I hate it, but it's locker room talk and it's one of those things." Good men distanced themselves from Trump's behavior quickly and publicly. Some professional athletes, for instance, disavowed this proverbial "locker room talk" through multiple interviews, statements and the \#notinmylockerroom Twitter hashtag.

While it may be that, as the Guardian put it, these "decent men" distanced themselves from "Trump men" in disavowing that particular sexist moment, the line between "decent" men and "Trump" men may be less clear than it appears at first glance. Take for example this blistering critique of Trump issued by American entertainer Steven Colbert:

You're not the POTUS. You're the BLOATUS. You're the glutton with the button. You're a regular Gorge Washington. You're the presi-dunce, but you're turning into a real prick-tator. Sir, you attract more skinheads than free Rogaine. You have more people marching against you than cancer. You talk like a sign language gorilla who got hit in the head. In fact, the only thing your mouth is good for is being Vladimir Putin's cock holster. Your presidential library is going to be a kids' menu and a couple of Juggs magazines. The only thing smaller than your hands is your tax returns, and you can take that any way you want. 
In this quite funny political commentary Colbert uses some of the same sexualized discourse that, when used by Trump, audiences found so problematic. However, this time the language was used to criticize a powerful man, the president, rather than to objectify women. Colbert insinuated that Trump and Putin were engaging in a same-sex relationship, and, importantly, that Trump is the sexually receptive (read less masculine) partner in that pair. Similarly Colbert insults the size of Trump's hands. In American folklore, the size of a man's hands and feet are thought to symbolize the size of his penis, the size of which itself is a symbol of one's virility and masculinity.

Colbert's use of emasculating, sexualized language to critique Trump complicates the Guardian's question about what type of man one is. Is one the kind of man who unapologetically talks about and engages in sexual assault? Is one the kind of man who opposes this sort of sexism by deploying homophobic and emasculating insults? In the rise of Trumpism we are seeing a contest over masculinity, over who qualifies as a "real man." This contest being waged not only by some obvious actors President Trump, his supporters and representatives for instance; it is a contest also waged by those who oppose the current administration and are perhaps actively working against the perpetuation of gender inequality.

The themes deployed by Trumpists and anti-Trumpists alike address a core component of masculinity in the global west - dominance (Connell, 1995; Pascoe, 2011; Peirce, 1995; Jaggar, 1983; Mackinnon, 1989). Through sexualized processes of confirmation and repudiation multiple actors in this political and social moment draw on and deploy understandings of normative masculinity as dominance - dominance over women and dominance over other, less masculine, men. The enactment of masculinized dominance is quite clear when looking at Trump, his supporters and members of his administration. However, the way in which the anti-Trumpists deploy these messages often work to obfuscate their deployment, something Tristan Bridges and I (2014) call "discursive distancing," or engaging in dominance practices which serve to position the actors as "decent" rather than Trump men, even while drawing on similar discourses of masculinity. 


\section{The Gender of Trumpism}

The election of President Trump is, in many ways, the story of American white, heterosexual masculinity, of a particularly noxious combination of racism, sexism and nationalism. Definitions of masculinity are culturally bound and "lives of particular groups of men are shaped by globally acting economic and political forces." (Connell, 2011, p. 9). As global economic relations are reordered, so are masculinities (Salzinger, 2016). This means that the trend of western economic and social decline increasingly noted by scholars (Hoang, 2015; Carlson, 2015) has specific ramifications for white western men and definitions of masculinity. This decline is a particularly masculinized one, both in effects and response. For certain groups of American men, global economic shifts have been particularly painful. Over the past 30 years many men in the United States have seen their real wages decline (Shierholz, 2013), their manufacturing jobs disappear (Autor, Dorn, \& Hanson, 2017) and felt the increasing absence of union power (Rosenfeld, Denice, \& Laird, 2016). As Arlie Hochschild writes, "it was an era of numerous subtle challenges to masculinity, it seemed" (2016, p. 202).

Not surprisingly, given the association of American masculinity with workplace success, whiteness, heterosexuality and social and economic self-sufficiency, this decline has been particularly felt by working class white men who have responded with both rage and mourning, a phenomenon sociologist Jennifer Carlson calls "mourning Mayberry" (2015). For American men, Mayberry (a fictional town in a television show from the 1950s) symbolizes an idyllic time in the American past. However, as Carlson points out, this time was idyllic only for a select few - white, middle and working class, heterosexual, Christian men. Carlson suggests that contemporary American white men are trying to regain "masculine dignity in the contexts of declining access to Mayberry America" (2015, p. 24). In many ways, their experience of a culture characterized by "a loss of American values, a loss of masculine dignity, and a loss of confidence in the state" (Carslon 2015, p. 11) drove the election of Trump.

For these men, what felt like an era of increasing gun control, endless government regulation, and too many laws protecting gender, sexual and racial/ethnic minorities meant that "the federal government wasn't on the side of men being manly" (Hochschild, 2016, p. 202). Trump's promise to 
"Make America Great Again" was in many ways a promise to "Make men 'great again' too, both fist-pounding, gun-toting guy-guys and high-flying entrepreneurs. To white, native born, heterosexual men he offered a solution to the dilemma they had long faced as the 'left-behinds' of the 1960s and 1970s celebration of other identities" (Hochschild 2016, p. 229). While not empirically true, the "deep story," in Hochschild's words, for these men was that gains for historically disadvantaged groups felt like losses for straight white men.

The rise of Trumpism, driven by the anger of these men, contradicts in many ways the familiar trope of a "narrative of progress, moving from tradition to modernity" (Connell, 2012, p. 7). This sort of thinking contrasts a "'traditional' masculinity (often understood as patriarchal and perhaps violent)" with "a 'modern' masculinity (often understood as more expressive, egalitarian and peacable)" (Connell, 2012, p. 7). The masculinity of the Trumpists, in this model, is "traditional" - harkening back to Mayberry and all that entails - while that of the anti-Trumpists is "modern" - looking forward in working for gender, racial and class equality. In looking at the discourses of masculinity that thread through these movements, however, it seems that similar discourses of masculinity as dominance undergird each. This seeming contradiction illustrates what Connell refers to as an "incoherence in gender relations" (2012, p. 4). Paying attention to this incoherence is central to evaluating the relationship between gender inequality and social change (Connell, 2012). Gender inequality is flexible and adaptive. What initially seems like change or progress (a wide scale protest against a politician's sexism for example), may actually be an example of more complicated social currents. The story of Trumpism and movements against it is an example of the tenacity of inequality in gendered discourses.

\section{Masculinity as Dominance}

Trump's discussion of locker room talk and Colbert's comments about Trump's tiny hands and sexual practices echoed comments and jokes made by the teenage boys I studied at an American high school, I call River High. These comments, jokes and actions were in part the way these young men engaged in masculinity as "a form of dominance usually expressed through 
sexualized discourses" (Pascoe, 2007, p. 5). The young men at River High regularly defined masculinity as dominance - displaying power over others, a lack of emotions, demonstrating competence, eschewing weakness and asserting one's heterosexuality, as well as the "repeated repudiation of the specter of failed masculinity" (Pascoe 2007, p. 5). These discourses entailed processes of confirmation through which young men asserted what I came to call a "compulsive heterosexuality," in which they exercised dominance over girls' bodies. Similarly, these young men engaged in repudiation processes in which they denied the specter of failed masculinity, imputing femininity and gayness to others in what I came to call a "fag discourse." What we see in both the Trumpist and anti-Trumpist movements are similar examples of masculinized dominance in which social actors claim masculinity through discourses and symbols of "compulsive heterosexuality" and divest others of it through the emasculating practices of a "fag discourse."

Compulsive heterosexuality entails exercising dominance over girls' bodies through sex talk ("grab "em in the pussy" for instance), physical prowess and sexual violence. In fact, listening to the teenage boys at River High talk about girls and what it meant to be a man, sounded a lot like Trump's "locker room talk." For instance, in talking about their plans for a formal winter dance one student, Josh, told another, Reggie, "I'll be fucking pissed if I don't get some." Reggie advised him "That's why you take a girl whose gonna do something. I got Jack Daniels!" Josh countered, "I got a big bag of marijuana...the sooner I get her drunk the sooner I get laid." Reggie triumphantly bragged, "I can get laid any time, anywhere." Later, Jerome complained that he was not "gonna get laid at Winter Ball." Josh admonished "That's why you gotta go for the younger ones fool! Like 12 years old!" Similarly, another student, Jay talked about a girl he thought was "hella ugly" but had "titties:" "She's a bitch. I might take her out to the street races and leave her there so she can get raped." The other boys in his class, as they often did in such conversations, responded in laughter.

Similarly, River High boys often physically constrained girls under the guise of flirtation. One time in the hallway a boy wrapped his arms around a girl and started to freak her, or grind his pelvis into hers as she struggled to get away. Another time a boy wrapped his arms around a girls' neck as if to put her in a headlock and held her there while his friend punched her in 
the stomach, albeit lightly and she squealed. Perhaps more dramatically, one boy, a drummer, rhythmically jabbed a girl in the crotch with his drumstick, while he yelled "get raped! get raped!" The constraint and touch of female bodies gets translated as masculinity, embedding sexualized meanings in which heterosexual flirting is coded as female helplessness and male bodily dominance. Touch is gendered -men touch women in different ways than women do men, they invade women's space and interrupt them more than women do to men.

As feminist scholar Adrienne Rich argued, heterosexuality not only describes sexual desires, practices and orientations; it is also a "political institution" (1980). The "enforcement of heterosexuality for women as a means of assuring male right of physical, economic and emotional access" is a central component of gender inequality. The locker room talk examples of "mythic story telling" (Kehily \& Nayak, 1997) in which boys and men tell humorous larger than life tales about their sexual adventures, their bodies, and girls' bodies are an important way in which men maintain sexual dominance over women. Men's sexual assault, discursive and physical, of women has long been theorized as a form of masculinized dominance over women's bodies (Mackinnon, 1989; Dworkin, 1991; Jeffreys, 1999; Cahill, 2001).

But of course, masculinity as dominance doesn't only entail dominance over women, it also entails dominance over other men. This dominance work renders other men unmasculine, feminized, weak and subordinate. This sort of repudiatory dominance work positions other men as failed men through sexualized discourses - either these men fail at masculinity or they fail to secure a claim on heterosexuality (sometimes, ironically, by subscribing to outdated notions of masculinity), something I came to call a "fag discourse." The fag discourse that proliferated among the young men I studied that primarily took the form of homophobic teasing, harassment and jokes. However, the use of the word has as much to do definitions of masculinity as it did with actual fear of other gay men. In other words, being subject to homophobic harassment has as much to do with failing at masculine tasks of competence, heterosexual prowess or in any way revealing weakness as it did with a sexual identity.

"Fag" was the ultimate insult, according to these young men. Jeremy, for instance, suggested that this insult reduced a boy to nothing, "To call 
someone gay or fag is like the lowest thing you can call someone. Because that's like saying that you're nothing." Many boys explained their frequent use of epithets like queer, gay and fag by asserting that, as Keith put it, "guys are just homophobic." However, boys make clear that this homophobia was as much about failing at tasks of masculinity as it was about fear of actual gay men. As J.L. said, "Fag, seriously, it has nothing to do with sexual preference at all. You could just be calling somebody an idiot, you know?" Revealing masculine incompetence in any way could render a boy subject to the epithet. As Ben said, "anything, literally anything" could render one vulnerable. "Like you were tying to turn a wrench the wrong way, 'dude you're a fag.' Even if a piece of meat drops out of your sandwich, 'you fag!'”

Of course, gendered repudiation doesn't always take a homophobic form. One can explicitly mock other men for failing at masculinity in a wide variety of ways.

Take Chad's words for example. Chad, an extremely popular football player at River High, described his sexual history like this:

When I was growin' up I started having sex in the 8th grade...The majority of the girls in 8th and 9th grade were just stupid. We already knew what we were doing. They didn't know what they were doing you know?... Like say, comin' over to our house like past 12. What else do you do past 12? Say we had a bottle of alcohol or something. I'm not saying we forced it upon them. I'm sayin'... (Pascoe, 2007)

While the incident Chad describes - plying underage women with alcohol in order to have sex with them - is one that many would agree would constitute rape, he self-consciously distances himself from rape ("I'm not saying we forced it upon them"). Indeed, he went on to share that his friends, "Kevin Goldsmith and uh, Calvin Johnson, they got charged with rape," while claiming that, in contrast, he never had to force a girl to have sex: "I'll never (be in) that predicament, you know. I've never had hard time, or had to you know, alter their thinking." The sort of sexual assault Kevin Goldsmith and Calvin Johnson participated in is something that other, less masculine guys do. By distancing himself from this practice, Chad confirms his own claim to masculine dominance - a claim which is 
stronger because he obtained sex without physical force. This is a process Jocelyn Hollander and I call "mobilizing rape," or the way in which men position other men as failed men or unmasculine because they use force to secure sexual access to women's bodies (Pascoe \& Hollander, 2016).

The discursive dominance that comprises western masculinity is sexualized - affirming one's power over women and their bodies, as well as divesting other men of their masculinity through feminizing them. Similar discourses can be traced across messages emerging from President Trump, his supporters and representatives as well as those who oppose him and his administration.

\section{Trumpism}

Masculinity as domination is expressed by Trump, his followers and administration in three main ways - bodily dominance, sexual assault and by positioning other men as sexually failed men.

Much like the boys at River High, President Trump engages in "sex talk" when he talks about women's bodies and what he can do to them. Judging by these comments, women, for Trump, often serve as potential sexual conquests. A CBS News video clip from the early 1990s in fact, shows Trump stepping of an escalator speaking briefly about a young girl also on the escalator. Trump asserts, "I'm going to be dating her in 10 years, can you believe it?" He was 46 at the time. Around the same time, after a youth choir performance outside of the Plaza Hotel in Manhattan, New York, Trump asked two of the female singers their ages. Upon learning they were 14 years old, Trump replied, "Wow! Just think - in a couple of years, I'll be dating you." Much like the boys at River High, Trump can assert dominance over women by positioning them as sex objects, framing them as agent-less recipients of his desire.

Similarly, much like the young men at River High, candidate Trump enacts bodily dominance over women in a variety of ways. His behavior during one of the presidential debates exemplifies this. The second presidential debate (the one in which then candidate Trump justified his locker room talk) did not feature the usual podiums behind which the candidates stood. Rather, in this debate the candidates were free to roam the stage. What ensued was an unusual practice, unusual enough that multiple 
commentators noted it. Candidate Trump stood behind candidate Clinton repeatedly, his much larger body hulking behind her. When candidate Clinton moved across the stage to make a point, he would follow. The Washington Post described his behavior as "looming behind Hillary Clinton like a mob boss" and "eager to dominate" comparing him to a schoolyard bully (Kaufman, 2016). Much like the boys who exercised dominance over women's bodies by constraining them or physically hurting them, Trump did it by taking up space and physically looming over Clinton in a quite ominous manner.

Similar dominance practices are enacted by those who support President Trump and his policies. They play the double meaning of Trump's last name to its fullest effect. Merriam Webster defines the word trump as "to get the better of" or "to override," in essence, to dominate. This word play appears on bumper stickers, signs and t-shirt sported by those who support him reading: "Trump that Bitch." This sort of gendered dominance is a rallying call, a moment of collective effervescence, a harkening back to a time when women weren't challenging male dominance and were kept in their place by law and custom. It's an example of "mourning Mayberry." Much like the working class boys I studied at River High, white male dominance had been challenged by years of sustained feminist as well as civil rights activism and in many ways assertions of normative white masculinity were a way to put women (and also racial minorities) back in their place symbolically, by "Trumping" them.

Trump's dominance over women is also displayed in his refusal to touch them. He has made it clear that women's bodies are repulsive him, saying of one reporter - "blood coming out of her wherever" and calling another "disgusting" for her need to pump breast milk (Suebsaeng, 2015). This revulsion was on global display in his refusal to shake German Chancellor Angela Merkel's hand. In a widely circulated video of the two meeting, photographers ask, as the world leaders sit next to each other "Do you want to have a handshake?" (Williams, 2017). The Guardian reported, "Trump says nothing, does nothing, and just stares straight ahead. He sits with that signature pout on his lips, legs splayed out, and posture bent forward...Merkel the offers a slight shrug and turns her head away." Trump's refusal to look at Chancellor Merkel or extend his hand seemingly answers the question. In this instance, he exercised dominance by simply 
ignoring her and not extending to her the same dignity that is traditionally awarded to other heads of state. This is, a man, of course, who actually said of women "You have to treat "em like shit," a philosophy that he apparently incorporates into diplomatic relations.

Trump's enthusiastic handshakes with male world leaders a different way for him to dominate other men. As Raewyn Connell argues, normative masculinity is sustained by men's dominance over other men as well as women (1995). President Trump, for example, shook Prime Minister Shinzo Abe's hand for 19 second in what the Guardian called a "strange jerky movement he deploys to dominate his counter parts." Trump yanks people toward him during these handshakes, once so violently grabbing Neil Gorsuch's arm that the judge lost his balance (Collett, 2017). Much was made of Canadian Prime Minister Justin Trudeau's preparation to counter Trump's handshake as he clearly went in prepared to resist the move by standing firm and placing his hand on Trump's shoulder to brace for the "yank." The Telegraph later joked about this meeting calling it "the biggest display of dominance in the history of Canada" (Boult \& Graham, 2017).

Other men are positioned by Trump and his representatives as weak, dangerous and less masculine men. Much like Chad, even though Trump has actually described his own participation in sexual assault, he positions other men as "bad" men who are the real sexual predators. Take for instance, his discussion of immigration from Mexico (which he ardently opposes) and people he proudly called "bad hombres:"

When Mexico sends its people, they're not sending their best. They're not sending you. They're not sending you. They're sending people that have lots of problems, and they're bringing those problems with us. They're bringing drugs. They're bringing crime. They're rapists. (Washington Post, 2015).

The identity of rapist is deflected from the white masculinity of the president and imposed upon male immigrants of color. President Trump, in casting immigrant men of color as rapists, exploits the gendered flexibility of identity afforded privileged groups (Bridges \& Pascoe, 2014). He "moblizes rape" distancing himself from his own sexually predatory behavior by projecting it on to other, less masucline men (Pascoe \& 
Hollander, 2016). His claim reflects a larger cultural practice in which the label of "rapist" is transferred to poor men and men of color, symbolically purifying white, middle class or educated men of this sort of undesirable behavior (Davis, 1983; Hondagneu-Sotelo \& Messner, 1994; Messner, 1993; Collins, 2005; Harper, Wardell \& McGuire, 2011).

This sort of rhetoric about dangerous racial/ethnic and national "others" is echoed throughout the Trump administation. Look at the words of James Mattis for instance, the Secretary of Defense, speaking about Operation Enduring Freedom four years into the conflict in 2005:

You go into Afghanistan, you got guys who slap women around for five years because they didn't wear a veil. You know, guys like that ain't got no manhood left anyway. So, it's a hell of a lot of fun to shoot them. (CNN, 2005).

Indeed, several years before his statement, a bomb was photographed on the USS Enterprise aircraft carrier in 2001 and was later dropped on Afghanistan. Scrawled on the side of it in spraypaint was the phrase "Hijack (sic) this fags" (Ducat, 2005). Presumably the members of the military who wrote that epithet did not think that the victims of the bomb were actual homosexuals, but sought to emasculate them with this homophobic epithet, much like Mattis did through framing them as men who were so unmasculine that they engaged in intimate partner violence.

Through these dominance practices, one establishes he is a "real man" by depriving others of masculinity - rendering them rapists, wife beaters, and perhaps simultaneously fags. This has the effect of bolstering one's own masculinity, denying another of humanity and positions one as a "good guy." If immigrants, men of color, Muslims are bad, failed men then white men who position them that way can make statements like this: "On International Women's Day, join me in honoring the critical role of women here in America \& around the world" or this "I have tremendous respect for women and the many roles they serve that are vital to the fabric of our society and our economy" - both tweets issued by President Trump. Trump can make these claims precisely because failed masculinity is projected onto other men - men of different religions, nationalities and citizenship. These other men, they are the less masculine bad men. Trump, however, is a good man who values women. 
In sum, Trump and Trumpists engage in similar processes of confirmation and repudiation I document among teenage boys - they position themselves as masculine through engaging in dominance practices over women and other men as well as repudiation practices that position other men as unmasculine failures.

\section{Opposing Trumpism}

As tempting as it may be in these contests over masculinity to assign a "bad" masculinity to Trump (much like Trump does to "bad hombres") it is clear when seeking to find the answer the Guardian's question, "Are you a Trump man or a decent man?" discourses of masculinity as dominance characterize anti-Trumpist sentiments as well. As indicated by Colbert's comments about oral sex between Trump and Putin and his insults about Trumps tiny hands it is clear that opposition to Trump is not outside of these contests over who is a "real man." Rather they can deploy discourses of masculinity that mirror those expressed by the teenage boys at River High and by Trump himself. The opposition to Trumpism can take the form of confirming that one is a "real man" because of one's good gender politics or by divesting Trump of his masculinity (much like Trump and his representatives do to other men). The anti-Trumpists engage in masculinity as dominance discourses in two ways - feminizing Trump and redefining "real men" to mean feminist men.

Colbert, for instance, is not alone in positioning Trump as gay. Examples of homophobic epithets lobbed at the president proliferate on social media. Take the following tweets for example:

@ realDonaldTrump dude you're a fag lol

Not even gonna read this article, but I dont think this dude could be anymore of a fag. "Bikers for Trump" (followed by two crying and laughing emojis).

Dude, You're president already and still worried about Hillary.

You're a whole joke...you're a fag! 
It's doubtful that these tweeters (or the many out there like them, if informal observation of online homophobia is any indication) think Donald Trump or his motorcycle riding supporters are actually gay. It's doubtful, much like the teenage boys at River High, that this tweeter actually thinks Donald Trump is attracted to other men. Rather these are examples of a fag discourse in which men are called fags or gay because they are, or perhaps more precisely in this case, to actively render them, weak and unmanly.

Other anti-Trumpism critiques reflect the eroticized Trump/Putin relationship addressed by Colbert. One protest featured huge puppet of President Trump, his mouth wrapped around a ball gag. The sign below the puppet read "Putin's little bitch." A meme of a (fictional) Time Magazine cover reads depicts President Trump sitting with his back to and face turned toward the camera, wearing a bridal gown and veil. The headline reads "Russian Bride of the year." One protest sign at the International Women's March featured President Trump as an infant in diapers being held aloft by Putin. These are a few examples of the plentiful images of him as a bride, wife, or male sexual partner of Putin that suggest perhaps rather than trumping the bitch (as his supporters cry), Trump himself IS the bitch.

Similarly, it is difficult not to pick up on the theme of size in many of the images and jokes critiquing President Trump. Take for instance, the "Tiny Trump" series of memes. These images feature an image of Trump that is made artificially small placed in variety of scenarios: being dressed by Kelly Ann Conway, greeting Putin, talking with Barak Obama, stepping off his plane with a double thumbs up, signing orders in the oval office, greeting Justin Trudeau, talking with Anderson Cooper, golfing and being led around holding Obama's hand while wearing a toddler dress. As illustrated by Colbert, the jokes about "tiny hands" are ubiquitous. Signs at protest marches read "keep your tiny hands off my body" or "keep your tiny hands off all our rights." Some websites even offer plastic "tiny hands" for sale. This message about size is an attempt to emasculate Trump. Real, adult men are large. They are tall. They have large hands. They can physically hold their own and dominate others. If real men are large and dominating (and perhaps use that dominance to intimidate women as in the presidential debate) then Trump's opponents can emasculate him by bringing him down to size. 
The anti-Trumpist framing of "real men" builds on this imagery of Trump as gay, emasculated, tiny, feminine and childlike. Anti-Trumpist messaging suggests that "real men" exhibit traits that Trump himself does not. As one truck bumper sticker reads: "Real Men Don't Tweet," referencing the president's seeming fondness for early morning tweet missives. Much gender-ado was made of Trump's particular manner of eating steak - well done with ketchup. Among the commentaries about this practice, was one tweet reading "Trump eats his steak well-done with ketchup?? Yeah, a real man's man. Why even bother? Order some chicken you pansie-ass." Other protest signs specifically define real men as feminist men, reading: "Strong women scare weak men;" "Strong men respect women;" "Men of quality do not fear equality;" "Real men don't grope;" or "Real men don't talk like that." Real men, in other words, are feminist men.

The messages that "real men" support women's equality is not limited to opposing this presidential administration, entire anti-violence campaigns are based on it. The My Strength is Not For Hurting anti-sexual assault campaign aimed at men, for example, encourages men to use their (presumed) strength for good (Masters, 2010; Murphy, 2009). This campaign aligns non-rapist men with a good masculinity through framing "real" and "strong" men as fundamentally different from (presumably weak and unmanly) rapists (Bridges \& Pascoe, 2014). The recent "Real Men Don't Buy Girls" campaign sought to shame men into not participating in sex trafficking. Similarly, participants in men's Walk a Mile in Her Shoes marches, as Tristan Bridges' research demonstrates, mock femininity even while advocating an end to gender-based violence (Bridges, 2010). Campaigns like this discursively separate "good" men who support gender equality from "bad" men who oppose it (Bridges \& Pascoe, 2014). This framing also symbolically purifies men participating in these movements rendering them in the words of the Gaurdian, "decent men." However, this decent masculinity is predicated upon some of the same tactics it critiques, such as asserting dominance over other men by rendering them effeminite, childlike, gay or as failed men. 


\section{Conclusion}

The causes and consequence of the election of Donald Trump are both deeply symbolic and devastatingly real. While Trump framed his "locker room talk" as "just words" as "things that people say," this sort of talk undergirds what feminist scholars call "rape culture" in which symbolic violence, especially humorous symbolic violence, dehumanizes women, reducing them to sexual objects. Indeed, "locker room talk" itself might be a term with which to normalize gendered and sexual violence that frames much of the contemporary gender order in the west. The effects of Trump's views on women (even apart from his policies that harm women) have been wide ranging. In fact, a study from the Wharton School of Business demonstrated through a series of lab-based experiments, a measurable "increase in men acting more aggressively toward women" (Huang \& Low, 2017) after the presidential election.

It seems little wonder that when faced with this level of sexism and misogyny protesters oppose Trumpism precisely by critiquing the rageful masculinity at the heart of it. The left has used similar tactics elsewhere. When white,right-wing, male activists took over a federal nature preserve in rural Oregon, for instance, critics on the left sent them homoerotic fan fiction and dildos, intending to humiliate them precisely because of their homophobia and sexism. Instances like these are masculinity standoffs between those who are "mourning Mayberry" and those who have worked so hard to make sure that it stays a part of the American past.

These types of masuclinity standoffs remind us that satire and protest are dicey issues. Feminist scholars studying anti-Trumpist movements warn that when we engage in resistance we need to be careful about what it looks like (Barber, 2017). They point out that perhaps unwittingly pro-feminist activism can actually reinscribe some of the problematic social order it seems to be critiquing, as is the case with some men's movements against gender based violence (Bridges \& Pascoe, 2014; Pascoe \& Hollander, 2016). Gendered "resistance...is fraught with danger...sometimes it challenges the gender order and sometimes it seems to bolster it" (Pascoe, 2007, p. 15).

Perhaps the anti-Trumpists who draw upon discourses of masculinity as dominance may do better to focus activism on questioning the foundation 
of a society that has required a particular form of masculinity from working class white men and then denied them the structural means to achieve it. The "deep story" told by Hochschild about the feelings of betrayal, sadness and attachment to a particular way of life by white, working class conservatives is instructive. Only by taking seriously the rage produced by economic inequality and the entitlement that constitutes whiteness can those who oppose political movements that serve to further disenfranchise multiple marginalized groups think about how to work against this form of masculinized dominance.

Such opposition entails focusing not on good men or bad men, but on the processes by which people are rendered good or bad men - the confirmation and repudiation processes documented here. It may be a delicious experience to use the tools of the dominant against those in power. It may provide a perverse sense of delight. But in the end, this gendered fight over what sort of nation the United States has been and will be needs to focus less on who is a "real men" and perhaps more on how these discourses of masculinity can reinscribe and exacerbate already existing gendered, classed and raced inequalities.

\section{Notes}

During United States, presidential elections, candidates customarily engage in a series of debates. In the 2016 presidential election, then candidates Hillary Clinton and Donald Trump continued this tradition.

\section{References}

Autor, D., Dorn, D., \& Hanson, G. (2017). When Work Disappears:

Manufacturing Decline and the Falling Marriage-Market Value of Men. NBER Working Paper No. 23173. Retrieved from http://www.nber.org/papers/w23173

Barber, K. (2017, April 12). Satire as Protest at the Women's March [Web $\log$ post]. Retrieved from

https://gendersociety.wordpress.com/2017/04/12/satire-as-protest-inthe-womens-march/

Bayoumi, M. (2017, March 18). What is it with Trump and handshakes?

This is getting awkward. The Guardian. Retrieved from 
138 Pascoe - Who is a Real Man? The Gender of Trumpism

https://www.theguardian.com/commentisfree/2017/mar/18/trumphandshakes-angela-merkel-awkward

Bordo, S. (2017). The Destruction of Hillary Clinton. Brooklyn: Melville House.

Boult, A., \& Graham, C. (2017, February 14). Justin Trudeau's handshake with Donald Trump the 'biggest display of dominance in the history of Canada'. The Telegraph. Retrieved from

http://www.telegraph.co.uk/news/2017/02/13/justin-trudeau-

becomes-latest-world-leader-brave-trumps-awkward/

Bridges, T., \& Pascoe, C. J. (2016). Masculinity, Inequality and the 2016 Presidential Election. ASA Footnotes. 44(8). Retrieved from

http://www.asanet.org/news-events/footnotes/dec-

2016/features/sociologists-reflect-2016-presidential-election.

Bridges, T., \& Pascoe, C. J. (2014). Hybrid masculinities: New directions in the sociology of men and masculinities. Sociology Compass, 8(3), 246-258. DOI: $10.1111 /$ soc4.12134

Bridges, T. (2010). Men Just Weren't Made To Do This. Performances of Drag at "Walk a Mile in Her Shoes" Marches. Gender \& Society, 24(1), 5-30. doi: 10.1177/0891243209356924

Cahill, A. (2001). Rethinking Rape. Ithaca, NY: Cornell University Press.

Carlson, J. (2015). Citizen-Protectors: The Everyday Politics of Guns in an Age of Decline. New York, NY: Oxford University Press.

CNN. (2005, February 4). General: It's "fun to shoot some people.” CNN. Retreived from http://www.cnn.com/2005/US/02/03/general.shoot/

Collett, P. (2017, February 15). What does Donald Trump's handshake say about him? The Guardian. Retrieved from https://www.theguardian.com/commentisfree/2017/feb/15/trumpyank-shake-us-president-handshakes-self-serving

Collins, P. H. (2005). Black Sexual Politics: African Americans, gender, and the new racism. New York: Routledge.

Connell, R. (2012). Masculinity Research and Global Change. Masculinities and Social Change, 1(1), 4-18. doi:

10.4471/mcs.2012.01

Connell, R. (2011). Confronting Equality: Gender, Knowledge and Global Change. Cambridge: Polity.

Connell, R. (1995). Masculinities. Stanford: Stanford University Press. 
Davis, A. (1983). Women, Race, \& Class. New York: Vintage Books. Ducat, S. (2005). The Wimp Factor: Gender Gaps, Holy Wars, and the Politics of Anxious Masculinity. Boston: Beacon.

Dworkin, A. (1991). Pornography: Men Possessing Women. New York: Plume.

Harper, S. R., Wardell, C. C., \& McGuire, K. M. (2011). Man of multiple identities: Complex individuality and identity intersectionality among college men. In J. A. Laker \& T. Davis (Eds.), Masculinities in higher education: Theoretical and practical considerations (pp. 8196). New York: Routledge.

Hoang, K. (2015). Dealing in Desire Asian Ascendancy, Western Decline, and the Hidden Currencies of Global Sex Work. Oakland, CA: University of California Press.

Hochschild, A. R. (2016). The Ecstatic Edge of Politics: Sociology and Donald Trump. Contemporary Sociology, 45(6), 683-689. doi: 10.1177/0094306116671947

Hondagneu-Sotelo, P., \& Messner, M. (1994). Gender displays and men's power: The 'new man; and the Mexican immigrant man. In H. Brod \& M. Kaufman (Eds.), Theorizing Masculinities (pp. 210-218). New York: Sage Publications.

Huang, J., \& Low C. (2016). Trumping Norms: Lab evidence on aggressive communication before and after the 2016 US presidential election. [Unpublished paper]. Retrieved from http://assets.wharton.upenn.edu/ corlow/HuangLow_PP.pdf

Jaggar, A. (1983). Feminist Politics and Human Nature. Lanham: Rowman \& Littlefield Publishers, Inc.

Jeffreys, S. (1999). Globalizing sexual exploitation: Sex tourism and the traffic in women. Leisure studies, 18(3), 179-196. doi: 10.1080/026143699374916

Kaufman, S. L. (2016, October 10). Why was trump lurking behind Clinton? How Body Language Dominated the Debate. The Washington Post. Retrieved from https://www.washingtonpost.com/news/arts-andentertainment/wp/2016/10/10/why-was-trump-lurking-behindclinton-how-body-language-dominated-thedebate/?utm_term=.19a7addcf106 
Kehily, M. J., \& Nayak, A. (1997). 'Lads and laughter': humour and the production of heterosexual hierarchies. Gender and Education, 9(1), 69-88. doi: 10.1080/09540259721466

MacKinnon, C. A. (1989). Toward a Feminist Theory of the State. Harvard University Press.

Masters, T. (2010). "My strength is not for hurting:" Men's anti-rape websites and their construction of masculinity and male sexuality.' Sexualities, 13(1), 33-46. doi: 10.1177/1363460709346115

Messner, M. (1993). "Changing men" and feminist politics in the United States. Theory and Society, 22(5), 723-737. Retrieved from http://www.jstor.org/stable/657993

Murphy, M. (2009). Can men stop rape? Visualizing gender in the "my strength is not for hurting" rape prevention campaign. Men and Masculinities, 12(1), 113-130. doi: 10.1177/1097184X09331752

Pascoe, C. J., \& Hollander, J. A. (2016). Good Guys Don't Rape: Gender, domination, and Mobilizing Rape. Gender \& Society, 30(1), 67-79. doi: $10.1177 / 0891243215612707$

Pascoe, C. J. (2007). Dude, You're a Fag. Berkeley: University of California Press.

Peirce, J. (1995). Gender Trials: Emotional Lives in Contemporary Law Firms. Berkeley: University of California Press.

Penny, L. (2017, April 10). Are You a Trump Man or a Decent Man? Time to Choose. The Guardian. Retrieved from

https://www.theguardian.com/commentisfree/2017/apr/10/trumpman-aggression-towards-women-us-election

Rich, A. (1980). Compulsory Heterosexuality and Lesbian Existence. Signs, 5(4), 631-660. doi: 10.1086/493756

Rosenfeld, J., Denice, P., \& Laird, J. (2016). Union Decline Lowers Wages of Nonunion Workers. Retrieved from

http://www.epi.org/publication/union-decline-lowers-wages-ofnonunion-workers-the-overlooked-reason-why-wages-are-stuck-andinequality-is-growing/

Salzinger, L. (2016) Re-Marking Men: Masculinity as a Terrain of the Neoliberal Economy. Critical Historical Studies, 3(1), 1-25. doi: $10.1086 / 685553$ 
Shierholz, H. (2013). The Wrong Route to Equality - Men's Declining Wages. Retrieved from http://www.epi.org/publication/wrong-routeequality-mens-declining-wages/

Suebsaeng, A. (2015, August 8). 'You Have to Treat 'Em like Shit': Before Megyn Kelly, Trump Dumped Wine on a Female Reporter. Daily Beast. Retrieved from http://www.thedailybeast.com/articles/2015/08/08/you-have-to-treatem-like-shit-before-megyn-kelly-trump-dumped-wine-on-a-femalereporter

The New York Times. (2016, October 8). Transcript: Donald Trumps Taped Comments about Women. The New York Times. Retrieved from https://www.nytimes.com/2016/10/08/us/donald-trump-tapetranscript.html

Washington Post. (2015, June 16). Full text: Donald Trump announces a presidential bid. Washington Post. Retrieved from https://www.washingtonpost.com/news/postpolitics/wp/2015/06/16/full-text-donald-trump-announces-apresidential-bid/

Williams, R. (2017, March 17). Donald Trump refuses to shake Angela Merkel's hand. The Independent. Retrieved from http://www.independent.co.uk/news/world/americas/uspolitics/donald-trump-angela-merkel-shake-hand-refusea7635911.html

C. J. Pascoe is Associate professor in Department of Sociology at the University of Oregon, United States.

Contact Address: Direct correspondence to C.J. Pascoe, Department of Sociology, Main Office, 720 PLC, 1291 University of Oregon, Eugene, OR, United States, email: cpascoe@uoregon.edu 